\title{
Pengaruh Perbedaan Sumber Energi Pakan (Jagung dan Pollard) terhadap Respon Fisiologis Kelinci New Zealand White Betina
}

\section{The Effect of Differences in Feed Sources of Energy (Corn and Pollard) on Physiological Response of New Zealand White Female's Rabbit}

\author{
R. Kurniawati", C. M. S. Lestari, dan E. Purbowati \\ Fakultas Peternakan dan Pertanian, Universitas Diponegoro, Semarang, 50275 \\ "E-mail: riskakurniawati416@gmail.com \\ (Diterima: 4 September 2017; Disetujui: 21 November 2017)
}

\begin{abstract}
ABSTRAK
Penelitian bertujuan untuk mengkaji respon fisiologis kelinci New Zealand White betina yang memperoleh pakan pelet dengan sumber energi yang berbeda. Penelitian ini dilaksanakan pada bulan Mei - Juli 2016 bertempat di Meteseh, Tembalang, Semarang. Materi yang digunakan adalah 18 ekor kelinci New Zealand White betina umur 4-5 bulan dengan rata-rata bobot badan 1,97 $\pm 0,32 \mathrm{~kg}(\mathrm{CV}=16,65 \%)$. Rancangan percobaan yang digunakan adalah rancangan acak lengkap dengan 3 perlakuan dan 6 ulangan. Parameter yang diamati adalah respon fisiologis meliputi denyut nadi, frekuensi napas dan suhu rektal. Hasil penelitian menunjukkan bahwa pemberian pakan pelet dengan sumber energi pakan yang berbeda tidak berpengaruh terhadap respon fisiologis ternak. Respon fisiologis kelinci New Zealand White hasil penelitian dalam kondisi normal. Rata-rata denyut nadi, frekuensi napas dan suhu rektal kelinci New Zealand White berturut-turut $140 \mathrm{kali} / \mathrm{menit}, 80 \mathrm{kali} / \mathrm{menit}$ dan $38,17^{\circ} \mathrm{C}$. Berdasarkan hasil penelitian dapat disimpulkan bahwa perlakuan pemberian sumber energi pakan pada kelinci New Zealand White betina menghasilkan respon fisiologis yang sama dan dalam kisaran normal.
\end{abstract}

Kata kunci: kelinci New Zealand White, pakan sumber energi, respon fisiologis

\section{ABSTRACT}

The aim of this research was to examine the physiological response of New Zealand White female rabbits which obtain pellet feed with different energy sources (corn and pollard). This research was conducted from May until July 2016 at Meteseh, Tembalang, Semarang. The material used was 18 New Zealand White females rabbits aged 4-5 months with an average body weight of $1.97 \pm 0.32 \mathrm{~kg}$ (CV $=16.65 \%$ ). The experimental design used was a complete randomized design with 3 treatments and 6 replication. The parameters observed in this study were physiological response including pulse, breath frequency, and rectal temperature. The results showed that the treatment of different sources of feed energy did not affect the physiological response of livestock. The physiological response of New Zealand White rabbits which were fed with different energy sources (corn and pollard) is still in normal condition. The average pulse rate, respiratory rate and rectal temperature of New Zealand White rabbits were 140 times/ min, 80 times/min and $38.17^{\circ} \mathrm{C}$, respectively. Based on the results of this study it can be concluded that the treatment of feed energy source produces the same physiological responses of female New Zealand White rabbit and within the normal range.

Keywords: different energy sources, physiological response, New Zealand White Rabbit

\section{PENDAHULUAN}

Kelinci New Zealand White (NZW) merupakan hewan yang memiliki kemampuan tumbuh dan berkembang biak yang cepat (Kaplan, 1979). Kelinci NZW merupakan hasil persilangan dari beberapa bangsa yaitu kelinci Flemish, American White dan Angora (Arrington dan Kelley, 1976). Menurut Agus dan Masanto (2010), karakteristik kelinci NZW adalah dada penuh, badannya medium, kaki depan agak pendek, kepala besar, bulu 
halus dan tebal, telinga besar dan tebal, bobot hidup dapat mencapai $5,44 \mathrm{~kg}$ dan mampu menghasikan anak sekelahiran 10-12 ekor. Produktivitas ternak kelinci dipengaruhi oleh faktor genetik lingkungan, pakan dan penyakit. Permasalahan yang dihadapi pada pemeliharaan kelinci di daerah beriklim panas adalah cekaman panas, kualitas pakan rendah dan mudah terserang penyakit (Nuriyasa et al., 2014).

Pakan mengandung zat nutrisi berupa karbohidrat, protein, lemak, vitamin dan mineral yang bermanfaat bagi pertumbuhan dan produktivitas ternak. Pakan dengan sumber energi yang berbeda dapat mempengaruhi kondisi fisiologis kelinci karena perbedaan proses fermentasi atau metabolisme pakan dalam tubuh ternak. Jagung dan pollard merupakan bahan pakan yang tinggi akan kandungan energi. Kandungan nutrisi jagung adalah $86 \%$ bahan kering (BK), abu 3,3\%, lemak 6,9\%, serat kasar (SK) 4,3\%, bahan ekstrak tanpa nitrogen (BETN) 61,8\% dan protein kasar (PK) 9,7\%, sedangkan kandungan nutrisi pollard adalah BK $86 \%$, abu 5,2\%, lemak 3,5\%, SK 15,7\%, BETN $51,9 \%$ dan PK 12,9\% (Hartadi, 1997).

Respon fisiologis merupakan indikator bagi ternak apakah ternak dalam kondisi normal atau tidak yang dipengaruhi oleh beberapa faktor di antaranya pakan dan temperatur lingkungan. Respon fisiologis menurut Naiddin et al. (2010) merupakan aktivitas fisiologis dalam tubuh ternak meliputi denyut nadi, frekuensi napas dan suhu rektal yang dipengaruhi oleh konsumsi pakan. Peningkatan produksi panas dalam tubuh akibat dari proses metabolisme pakan menyebabkan ternak akan mempertahankan temperatur tubuhnya melalui proses termoregulasi (Frandson, 1992), sehingga ternak tetap dalam kondisi normal. Pelepasan panas tubuh ditandai dengan meningkatnya denyut jantung dan frekuensi napas. Peningkatan frekuensi napas bertujuan untuk membantu mengendalikan suhu tubuh. Suhu rektal merupakan respon terakhir dari gambaran kondisi fisiologis seekor ternak.
Penelitian ini bertujuan untuk mengkaji respon fisiologis kelinci New Zealand White betina yang memperoleh pakan pelet dengan sumber energi yang berbeda. Manfaat yang diharapkan dari penelitian ini adalah memperoleh informasi mengenai pengaruh pemberian pakan sumber energi terhadap respon fisiologis kelinci NZW, sehingga dapat memberikan rekomendasi kepada peternak mengenai pakan sumber energi yang baik untuk kelinci secara fisiologis.

\section{METODE}

Penelitian ini dilaksanakan pada bulan Mei-Juli 2016, di daerah Meteseh, Tembalang, Semarang.

\section{Materi penelitian}

Materi yang digunakan dalam penelitian adalah 18 ekor kelinci NZW betina umur 4-5 bulan dengan rata-rata bobot badan 1,97 \pm $0,32 \mathrm{~kg}(\mathrm{CV}=16,65 \%)$. Pakan yang diberikan berupa pelet yang disusun dengan kandungan PK $16 \%$ dan digestible energy (DE) 2.500 $\mathrm{kkal} / \mathrm{kg}$ (iso protein dan iso energi). Bahan pakan penyusun pelet berupa jagung dan/atau pollard, bungkil kedelai, molasses, garam, arang aktif, wheat bran, dedak kasar dan dedak halus. Komposisi bahan pakan penelitian terdapat dalam Tabel 1, sedangkan kandungan nutrisi pakan pelet dapat dilihat pada Tabel 2. Alat yang digunakan pada penelitian ini adalah stetoscop untuk mengukur denyut nadi ternak, stopwatch untuk mengukur frekuensi napas ternak, thermometer klinis untuk mengukur suhu rektal ternak serta thermohigrometer untuk mengukur suhu dan kelembapan dalam dan luar kandang.

\section{Metode penelitian}

Penelitian menggunakan rancangan acak lengkap (RAL) dengan 3 perlakuan dan 6 ulangan. Perlakuan yang diterapkan yaitu $\mathrm{TI}=$ (jagung), $\mathrm{T} 2=$ (pollard) dan $\mathrm{T} 3$ $=$ (jagung + pollard $)$. Parameter yang diamati adalah respon fisiologis meliputi denyut nadi, frekuensi napas dan suhu rektal. Parameter pendukung yaitu konsumsi bahan kering 
Tabel 1. Komposisi Bahan Pakan Pelet yang Digunakan dalam Penelitian.

\begin{tabular}{lccc}
\hline Bahan Pakan (\%) & T1 & T2 & T3 \\
\hline Jagung & 30,0 & 0,0 & 15,0 \\
Pollard & 0,0 & 30,0 & 15,0 \\
Dedak halus & 22,5 & 18,0 & 25,0 \\
Bungkil kedelai & 23,5 & 18,0 & 20,5 \\
Wheat bran & 6,5 & 19,0 & 11,5 \\
Mollases & 1,0 & 1,0 & 1,0 \\
Dedak kasar & 16,5 & 14,0 & 12,0 \\
\hline Jumlah & 100 & 100 & 100 \\
\hline
\end{tabular}

Tabel 2. Kandungan Nutrisi Pakan Pelet.

\begin{tabular}{cccccc}
\hline \multirow{2}{*}{ Perlakuan } & \multicolumn{5}{c}{ Kandungan Nutrisi } \\
\cline { 2 - 6 } & GE $(\mathrm{kkal} / \mathrm{kg})$ & PK $(\%)$ & SK $(\%)$ & LK (\%) & Abu (\%) \\
\hline T1 & 3.951 & 17 & 13,13 & 1,98 & 8,04 \\
T2 & 4.016 & 15,07 & 13,71 & 1,72 & 10,98 \\
T3 & 4.347 & 14,9 & 16,27 & 1,77 & 9,49 \\
\hline
\end{tabular}

Sumber: Hasil Analisis di Laboratorium Ilmu Nutrisi dan Makanan Ternak, Universitas Diponegoro Semarang, 2016.

(BK) pakan, konsumsi energi, suhu dan kelembaban kandang. Penelitian dilakukan dalam beberapa tahap yaitu tahap persiapan (4 minggu), adaptasi (1 minggu), pendahuluan (1 minggu) dan perlakuan (9 minggu). Data yang diperoleh dianalisis dengan analisis variansi (uji F) dengan membandingkan $\mathrm{F}$ hitung dengan $\mathrm{F}$ tabel 5\% (Gomez dan Gomez, 1995).

\section{HASIL DAN PEMBAHASAN}

\section{Konsumsi Pakan}

Rata-rata konsumsi BK dan energi pakan kelinci NZW Betina yang memperoleh pakan sumber energi berbeda seperti pada Tabel 3. Analisis statistik menunjukkan bahwa perlakuan tidak berpengaruh terhadap konsumsi BK total maupun energi pakan. Pakan pelet yang disusun dengan kandungan PK dan DE yang sama dengan bahan pakan sumber energi berbeda tidak mempengaruhi konsumsi BK pakan.

Rata-rata Konsumsi BK hasil penelitian sebesar 78,54 g/hari. Konsumsi BK kelinci NZW pada penelitian tergolong rendah dengan rata-rata $78,54 \mathrm{~g} /$ hari dibandingkan dengan penelitian dari Rizqiani (2011) yaitu sebesar 92,25-117,78 g/hari. Faktor pembatas konsumsi BK ternak yaitu kandungan energi. Menurut Pamungkas et al. (2013) bahwa semakin tinggi penggunaan jagung/pollard dalam bahan pakan maka akan menurunkan konsumsi total kelinci, hal ini karena tingginya kandungan energi pada jagung/ pollard. Konsumsi BK pakan sangat penting bagi pertumbuhan ternak, karena menurut Arrington dan Kelley (1976) kekurangan nutrisi dapat menyebabkan pertumbuhan lambat, reproduksi yang tidak efisien dan cenderung sakit. Faktor-faktor yang dapat mempengaruhi konsumsi BK antara lain palatabilitas, kemampuan ternak dalam mencerna pakan, serta status kesehatan ternak (Lubis, 1992). Menurut Church dan Pond yang disitasi oleh Rizqiani (2011) palatabilitas meliputi tekstur, bau, rasa dan suhu dari pakan mempengaruhi tingkat konsumsi kelinci. Kecernaan pakan yang tinggi menghasilkan produksi ternak yang tinggi. Menurut Susanti dan Marhaeniyanto (2007) bahwa komposisi ransum, bentuk fisik dari ransum, jumlah ransum yang diberikan dan kandungan nutrisi pakan mempengaruhi kecernaan pakan. Kesehatan ternak mempengaruhi performa dan produkstivitas ternak. Menurut Arrington dan Kelly (1976) penyakit menyebabkan penurunan konsumsi ternak dan kerugian ekonomi akibat berkurangnya kinerja ternak 
Vol. 20 (1): 1-7

Tabel 3. Konsumsi BK dan konsumsi energi pakan pada kelinci New Zealand White betina.

\begin{tabular}{lccc}
\hline \multirow{2}{*}{ Parameter } & \multicolumn{3}{c}{ Perlakuan } \\
\cline { 2 - 4 } & $\mathrm{T} 1$ & $\mathrm{~T} 2$ & $\mathrm{~T} 3$ \\
\hline Konsumsi BK Pakan (g/hari) & 77,88 & 78,68 & 78,97 \\
Konsumsi Energi (kkal/g) & 307,69 & 315,99 & 343,29 \\
\hline
\end{tabular}

bahkan kematian.

Konsumsi energi pada kelinci NZW betina yang diberi pakan dengan sumber energi jagung dan atau pollard tidak tidak berbeda nyata (Tabel 3) dengan rata-rata sebesar $322,34 \mathrm{kkal} / \mathrm{g}$. Konsumsi energi kelinci NZW pada penelitian tergolong rendah dengan ratarata $322,34 \mathrm{kkal} / \mathrm{kg}$ dibandingkan dengan penelitian Rizqiani (2011) sebesar 46,17$62,74 \mathrm{~g} / \mathrm{ekor} / \mathrm{hari}$. Konsumsi energi pakan dipengaruhi oleh besar kecilnya konsumsi BK. Pakan sumber energi merupakan komponen penting bagi tubuh ternak yang digunakan untuk hidup pokok dan pertumbuhan. Ternak kelinci mampu memanfaatkan pakan sumber energi yang berasal dari hijauan maupun konsentrat karena sistem pencernaan yang sederhana dengan cecum yang besar (Blakely dan Bade, 1994). Menurut Tillman et al. (1998) defisiensi energi dapat menyebabkan turunnya bobot badan sehingga pertambahan bobot badan ternak terhambat.

\section{Respon Fisiologis Kelinci New Zealand White}

Respon fisiologis ternak hasil penelitian meliputi denyut nadi, frekuensi napas dan suhu rektal pada kelinci NZW betina yang memperoleh pakan dengan sumber energi berbeda ditampilkan pada Tabel 2. Analisis statistik menunjukkan bahwa perlakuan tidak berpengaruh nyata terhadap respon fisiologis ternak. Respon fisiologis kelinci New Zealand White yang mendapat pakan dengan sumber energi berbeda dalam kondisi normal. Hal ini karena konsumsi BK dan energi yang berbeda tidak nyata. Pakan sumber energi baik dari jagung dan atau pollard yang masuk ke dalam tubuh ternak menghasilkan panas hasil dari proses metabolisme. Namun oleh ternak, panas tersebut digunakan untuk mempertahankan kondisi homeostasis. Hal ini sesuai dengan pendapat dari Suherman dan Purwanto (2015) bahwa pakan yang dikonsumsi ternak bisa berpengaruh meningkatkan lajuproduksi panas dalam tubuh atau disebut juga dengan efek kalorigenik pakan dan untuk mempertahankan kondisi homeostasis, ternak memerlukan energi yang cukup. Suhu dan kelembaban rata-rata kandang penelitian sebesar $27,69^{\circ} \mathrm{C}$ dan $79 \%$. Suhu dan kelembaban tersebut masih dalam zona nyaman bagi ternak kelinci sebesar $21,87-31,13^{\circ} \mathrm{C}$ dan $80-86 \%$ (Kamal et al., 2010), sehingga menyebabkan respon fisiologis ternak kelinci yang normal. Hal ini karena suhu dan kelembaban kandang mempengaruhi respon fisiologis ternak.

\section{Denyut Nadi}

Rata-rata denyut nadi kelinci NZW betina hasil penelitian perlakuan T1 (143 kali/ menit), T2 (137 kali/menit) dan T3 (140 kali/ menit) pada suhu dan kelembapan sebesar $27,69^{\circ} \mathrm{C}$ dan $79 \%$ menunjukkan berbeda tidak nyata. Denyut nadi kelinci tersebut termasuk normal dengan rata-rata $140 \mathrm{kali} / \mathrm{menit}$. Denyut nadi kelinci yang normal disebabkan oleh suhu dan kelembaban kandang yang optimal. Suhu dan kelembaban kandang penelitian termasuk normal. Menurut Nursita et al. (2013) bahwa suhu dan kelembapan optimal bagi ternak kelinci yaitu $25^{\circ} \mathrm{C}$ dan $80 \%$. Penelitian Arrington dan Kelley (1976) menunjukkan bahwa denyut nadi kelinci normal berkisar antara 123-304 kali/ menit dengan rata-rata $205 \mathrm{kali} / \mathrm{menit}$. Pakan (pelet) yang disusun dengan kandungan PK dan DE yang sama dengan bahan pakan sumber energi berbeda tidak mempengaruhi denyut nadi kelinci. Kelinci yang mendapat ketiga perlakuan pakan mendapat tambahan beban panas yang sama yang berasal dari energi pakan yang berbeda sehingga proses thermoregulasi tubuh berjalan normal, hal ini dikarenakan konsumsi BK dan energi juga tidak berbeda nyata. Hal ini dapat dinyatakan 
Tabel 4. Denyut nadi, frekuensi napas dan suhu rektal kelinci New Zealand White betina yang memperoleh pakan sumber energi berbeda.

\begin{tabular}{lccc}
\hline \multirow{2}{*}{ Parameter } & \multicolumn{3}{c}{ Perlakuan } \\
\cline { 2 - 4 } & $\mathrm{T} 1$ & $\mathrm{~T} 2$ & $\mathrm{~T} 3$ \\
\hline Denyut Nadi (kali/menit) & 143,00 & 137,00 & 140,00 \\
Frekuensi Napas (kali/menit) & 81,00 & 80,00 & 80,00 \\
Suhu Rektal $\left({ }^{\circ} \mathrm{C}\right)$ & 38,12 & 38,28 & 38,12 \\
\hline
\end{tabular}

bahwa kemampuan ternak dalam melepas panas hampir sama. Suherman dan Purwanto (2015) menyatakan bahwa konsumsi energi yang tinggi, produksi panas ternak semakin tinggi pula diakibatkan energi yang berasal dari ransum merupakan tambahan beban panas.

\section{Frekuensi Napas}

Frekuensi napas kelinci NZW betina perlakuan T1 (81 kali $/$ menit), T2 (80kali/menit) dan T3 (80 kali/menit) menunjukkan berbeda tidak nyata. Frekuensi napas ternak kelinci New NZW betina tersebut termasuk normal dengan rata-rata $80 \mathrm{kali} / \mathrm{menit}$. Frekuensi napas dipengaruhi oleh suhu dan kelembaban kandang. Suhu dan kelembaban yang optimal akan menghasilkan frekuensi napas ternak yang normal. Suhu dan kelembaban yang tinggi menyebabkan ternak mempercepat proses pelepasan panas dengan cara evaporasi dari saluran pernafasan. Nursita et al. (2013) menyatakan bahwa frekuensi napas kelinci berkisar antara $70-76 \mathrm{kali} /$ menit, sedangkan frekuensi napas kelinci menurut Arrington dan Kelley (1976) sebesar 36-56 kali/menit dengan rata-rata 46 kali/menit. Frekuensi napas kelinci penelitian tergolong lebih tinggi daripada penelitian dari Arrington dan Kelley (1976), hal ini dikarenakan perbedaan iklim yaitu iklim tropis dan subtropis. Kelinci penelitian hidup di daerah beriklim tropis sehingga menghasilkan frekuensi napas yang lebih tinggi. Perlakuan sumber energi yang berbeda tidak mempengaruhi frekuensi napas ternak kelinci. Mardiono (2016) menyatakan bahwa frekuensi napas dipengaruhi oleh produksi panas metabolis dan frekuensi denyut nadi. Produksi panas metabolis kelinci yang dihasilkan oleh sumber energi pakan yang berbeda diduga tidak berbeda karena konsumsi energi kelinci berbeda tidak nyata. Denyut nadi yang normal menjadi indikasi frekuensi napas yang normal pula. Menurut Nuriyasa et al. (2014) bahwa mempercepat laju respirasi merupakan cara yang paling efektif untuk menyeimbangkan panas tubuh. Faktor lain yang dapat menyebabkan peningkatan laju respirasi pada ternak kelinci yaitu ternak dalam keadaan ketakutan yaitu mencapai 200-300 kali/menit (Nursita et al., 2013).

\section{Suhu Rektal}

Suhu rektal mewakili temperatur seluruh bagian tubuh ternak karena merupakan hasil rata-rata pengukuran semua jaringan tubuh (Esmay, 1978). Suhu rektal kelinci New Zealand White betina perlakuan $\mathrm{T} 1\left(38,12^{\circ} \mathrm{C}\right)$, $\mathrm{T} 2\left(38,28^{\circ} \mathrm{C}\right)$ dan $\mathrm{T} 3\left(38,12^{\circ} \mathrm{C}\right)$ menunjukkan berbeda tidak nyata. Suhu rektal ternak kelinci tersebut termasuk dalam kisaran normal dengan rata-rata $38,17^{\circ} \mathrm{C}$. Hal ini dikarenakan suhu dan kelembaban kandang dalam keadaan normal. Menurut Arrington dan Kelley (1976) suhu rektal yang normal pada ternak kelinci sebesar $38,94^{\circ} \mathrm{C}$. Perlakuan pakan sumber energi yang berbeda tidak mempengaruhi suhu rektal kelinci NZW betina. Menurut Nuriyasa et al. (2014) apabila perlakuan ransum yang berbeda tidak mempengaruhi suhu rektal, hal ini mengindikasikan bahwa panas metabolisme yang dihasilkan dari sumber energi pakan yang berbeda oleh ternak kelinci belum berpengaruh pada suhu rektal. Panas pada tubuh kelinci yang terukur sebagai suhu rektal berasal dari panas metabolisme dan panas dari lingkungan. Menurut pendapat Suherman dan Purwanto (2015) suhu rektal ternak akan mencapai lebih dari $40^{\circ} \mathrm{C}$ pada suhu lingkungan yang mencapai $32,2^{\circ} \mathrm{C}$. Hal ini mengindikasikan fungsi tubuh bekerja 
secara ekstra untuk mencapai keseimbangan panas yang baik.

\section{KESIMPULAN}

Pakan dengan sumber energi berbeda (jagung dan pollard) menghasilkan respon fisiologis yang sama pada kelinci New Zealand White betina yang dilihat dari denyut nadi, frekuensi napas dan suhu rektal. Kondisi fisiologis kelinci pada penelitian ini masih dalam kondisi normal.

\section{DAFTAR PUSTAKA}

Agus, A dan R. Masanto. 2010. Beternak Kelinci Potong. Penebar Swadaya. Jakarta.

Arrington, L.R. dan K.C. Kelley. 1976. Domestic Rabbit Biology and Production. The University Presses of Florida. Gainesville.

Blakely, J dan D.H Bade. 1994. Ilmu Peternakan. Edisi ke-4. Gadjah Mada University Press. Yogjakarta. (Diterjemahkan Oleh: B. Srigandono)

Esmay, M.L. 1978. Principles of Animal Environment. Avi Publishing Company, Inc., Westport, Connecticut. p. 17-33.

Frandson, R.D. 1992. Anatomi dan Fisiologi Ternak. Edisi ke-4. Gadjah Mada University Press, Yogjakarta. (Diterjemahkan Oleh: B. Srigandono dan K. Praseno).

Gomez, K.A. dan A.A. Gomez. 1995. Prosedur Statistik untuk Penelitian Pertanian. Edisis ke-2. Universitas Indonesia Press. Jakarta.

Hartadi, H. 1997. Tabel Komposisi Pakan untuk Indonesia. Cetakan ke-2. UGM Press. Yogjakarta.

Kamal, A., Yamani, dan M. Hassan. 2010. Adaptability of Rabbit to the Hot Climate. http://resource.ciheam.org/ om/pdf/c.08/95605280. Diakses pada 3 Maret 2017 pukul 18.30 WIB.
Kaplan, H.M. 1979. The Rabbit, a Model for the Principles of Mammalian Physiology and Surgery. Academic Press. London.

Lubis, D.A. 1992. Ilmu Makanan Ternak. Cetakan II. PT Pembangunan, Jakarta.

Mardiono. 2016. Respon Fisiologis Sapi Madura Jantan yang Mendapat Level Pakan yang Berbeda. Universitas Diponegoro, Semarang (Skripsi Sarjana Peternakan).

Naiddin, A., M.N. Rokhmat, S. Dartosukarno, M. Arifin dan A. Purnomoadi. 2010. Respon fisiologis dan profil darah sapi Peranakan Ongole (PO) yang diberi pakan ampas teh dalam level yang berbeda. Dalam: L. H. Prasetyo, L Natalia, dan S. Iskandar (Editor). 2010. Prosiding Seminar Nasional Teknologi Peternakan dan Veteriner. Bogor 3-4 Agustus 2010. Badan Penelitian dan Pengembangan Peternakan, Bogor. Hal. 217-223.

Nuriyasa, I.M., N.G.K. Roni, E. Puspani, D.P.M.A. Candrawati, I.W. Wirawan dan A.W. Puger. 2014. Respons fisiologi kelinci lokal yang diberi ransum menggunakan ampas tahu yang disuplementasi ragi tape pada jenis kandang berbeda. Majalah Ilmiah Peternakan. 17 (2): 61-65.

Nursita, I.W., N. Cholis dan A. Kristianti. 2013. Status fisiologi dan pertambahan bobot badan kelinci jantan lokal lepas sapih pada perkandangan dengan bahan atap dan ketinggian kandang berbeda. Jurnal Ilmu Peternakan, 23 (1): 1 - 6.

Pamungkas, G.P.C., Kusmartono dan Hermanto. 2013. Pengaruh suplementasi biji jagung (Zea mays) terhadap jumlah konsumsi pakan, konversi pakan dan pertambahan bobot badan pada kambing Peranakan Boer. Program Studi Peternakan Universitas Brawijaya, Malang.

Rizqiani, A. 2011. Performa Kelinci Jantan Lokal Peranakan New Zealand White 
yang Diberi Pakan Silase atau Pellet Ransum Komplit. Fakultas Peternakan, Institut Pertanian Bogor. (Skripsi).

Suherman, D. dan B.P. Purwanto. 2015. Respon fisiologis sapi perah dara Fries Hollad yang diberi konsentrat dengan tingkat energi berbeda. Jurnal Sains Peternakan Indonesia. 10 (1): 13-21.

Susanti, S. dan E. Marhaeniyanto. 2007. Kecernaan, retensi nitrogen dan hubungannya dengan produksi susu pada sapi peranakan Friesian Holstein (PFH) yang diberi pakan pollard dan bekatul. Jurnal Protein. 15 (2): 141147.

Tillman, A.D., S. Reksohadiprojdo, S. Prawirokusumo, H. Hartadi dan S. Lebdosoekojo. 1998. Ilmu Makanan Ternak Dasar. Edisi ke-6. Gadjah Mada University, Yogjakarta. 